\title{
Orphan pensioners and migrating grandparents: the impact of mass migration on older people in rural Albania
}

\author{
RUSSELL KING* AND JULIE VULLNETARI*
}

\begin{abstract}
Since 1990 Albania has witnessed rural outmigration on a massive scale: both abroad, chiefly to Italy and Greece but increasingly to other countries too, and internally to Tirana and other major towns. The scale of this migration has been such as to disrupt multi-generational rural social and kinship systems which, before 1990, were strongly focused around cohesive family bonds and paternalistic state directives and provisions for all members of the population. Particularly vulnerable in this sudden rural dislocation have been older people, often left behind by their migrating children, creating the phenomenon of socially-isolated 'elderly orphans'. Remittances may cushion this social isolation somewhat, but loss of children and grandchildren through emigration removes older people's self-respect and raison d'être in Albanian family life. This paper, based on fieldwork and interviews in regions of heavy outmigration in northern and southern Albania, examines the human impact of emigration on the older people who are left behind and on their coping mechanisms, one of which is to decide to follow their children abroad to provide childcare to their grandchildren whilst the 'middle generation' of working-age parents can both engage in paid work.
\end{abstract}

KEY WORDS - Albania, migration, older people, grandparenting, transnational care.

Address for correspondence: Prof. Russell King, Sussex Centre for Migration Research, School of Social Sciences and Cultural Studies, University of Sussex, Brighton BN1 9SH, UK. Email R.King@sussex.ac.uk

[The Version of Record of this manuscript has been published and is available in Ageing \& Society; October 2006; DOI: 10.1017/So144686Xo6005125].

\footnotetext{
${ }^{*}$ Sussex Centre for Migration Research, University of Sussex, UK.
} 


\section{Introduction}

Studies on migration - which, by their very nature, tend to focus on and follow the migrants - rarely explore in-depth the impact of migration on the communities 'left behind'. In most cases, migration is a selective process, it being younger adults who leave, so the residual or non-migrant population becomes disproportionately made up of older people - typically the parents and elderly relatives of the migrants. Where studies of regions and communities of outmigration have been made, the general focus has been on the demographics of depopulation and changing age-sex structures (see, for example, King and Killingbeck 1989; Lowenthal and Comitas 1962; White 1980); there has been less of a willingness to engage in qualitative studies of the human impact of outmigration on residual communities. There are, however, a very few notable exceptions, such as Brody's Inishkillane (1983), a classic study of the west of Ireland with many moving passages on the social isolation felt by elderly bachelor farmers living on isolated homesteads, and Kreager's recent paper on the vulnerability of older villagers affected by rural-urban migration in Indonesia (Kreager 2006).

In this paper we examine the impact of the recent mass emigration from Albania on older people who remain in the villages. Since 1990 Albania has witnessed an emigration of epic proportions. After more than four decades of communist rule under the Stalinist dictatorship of Enver Hoxha, during which emigration was forbidden (attempts to escape were punished by long imprisonment or death), Albania witnessed an 'emigration explosion' in the early 1990s which saw tens of thousands of desperate people streaming over the mountainous border into Greece and commandeering ships to sail to Italy (Barjaba and King 2005; King 2003). Emigration has continued at a high rate over the ensuing decade. According to the results of the 2001 Census, there was a net emigration of more than 600,000 during 1989-2001, most of the emigrants being young adult males aged 18-35 (INSTAT 2002). More recent estimates from the Government of Albania, published in its National Strategy on Migration (2004: 40), increase this figure to 1 million, equivalent to one quarter of the total Albanian population. The main destinations for the migrants are Greece $(600,000)$ and Italy $(250,000)$. Substantial emigration has also taken place recently to the United Kingdom and North America, but there are no reliable estimates on the scale of this. 
Alongside emigration, and for many families intertwined with it too, is internal migration: between 1989 and 2001 355,230 Albanians moved to a different district (there are 36 districts in the country) and 252,735 internally migrated between the larger 12 prefectures (Carletto et al. 2004: 19; INSTAT 2004a: 13). Much of this migration was rural-to-urban and to the Tirana-Durrës urban-economic core of the country; indeed at the prefecture level Tirana (54\%) and Durrës (18\%) received nearly three-quarters of all internal migrants; and the city of Tirana increased its population by $42 \%$ (King 2004a). Meanwhile, in some of the northern and southern mountain districts, emigration and internal outmigration caused population losses of more than a third during 1989-2001, and as high as 55\% in the case of Delvinë, close to the Greek border.

[Figure 1 about here]

Figure 1. Population distributions in Albania, 1989-2001.

Notes: (a) Administrative districts. (b) The expulsion index, i.e. gross out-migration as a percentage of the 1989 population. (c) Elderly demographic-dependency ratio, i.e. ratio of population aged $65+$ years to that aged 15-65 years, 2001.

Census data reveal not only dramatic population losses due to heavy outmigration in most rural and mountain areas, but also a resulting much older age structure in these demographically declining districts. Figure 1 shows, for the districts (Figure 1a), the spatial pattern of migratory loss 1989-2001, and the elderly dependency ratio for 2001. The 'expulsion index' (Figure 1b) is the combined gross outmigration due to emigration and internal outflow, indexed against the population of each district in 1989; put another way, it is the share of population living in each district in 1989 that no longer lives there in 2001 (Carletto et al. 2004: 8). Gross outmigration is seen to be particularly high in interior mountain districts in the far north and far south of the country: areas where fieldwork for this paper was carried out. In the north most outmigration is internal, towards Tirana and other major towns, although there is some emigration to Greece, Italy and, since the late 1990s, to the UK. In the south most outmovement is external, especially to nearby Greece, and, building on much earlier (pre-communist) migration streams, to North America and Australia. 
The elderly demographic dependency index (Figure 1c) is the ratio of the number of persons aged $65^{+}$to the population aged 15-64, for 2001. On the whole, and despite massive emigration, this ratio remains quite low at $12 \%$ nationally; only in the south are there several districts where the ratio is above $20 \%$. However, several other facts qualify this overall impression. First, the Albanian population still has a predominantly young age structure because the birth rate remained high until very recently. Total fertility rate (the average number of children given birth per woman over her reproductive life-cycle) was, in round numbers, 7 in 1960, 5 in 1970, 4 in 1980 and 3 in 1990 (INSTAT 2002: 24). Second, the higher elderly ratio in the south also reflects a past history of lower birth rates and greater longevity in this traditionally more 'developed' part of Albania (Sjöberg 1989: 103-5). Third, much emigration, especially to Greece, is rather short-term and so may not be recorded by the census or by municipal registers, which enumerate temporary migrants as present in the village, whereas in fact they are not. And finally, much higher elderly ratios - up to $66 \%$ - are recorded at the municipality or commune level (INSTAT 2004b: 19), indicating therefore a much higher predominance of older people in many rural settlements.

Other data broadly confirm these aggregate patterns. According to Sokoli and Axhemi (2000), in the early and mid 1990s, $71 \%$ of emigration abroad was made up of young men aged 20-34 years; 60\% of emigrants were single. However, female emigration has increased, both absolutely and as a proportion of total emigration, since the mid-1990s, as Albanian emigration takes on an increasingly long-term, family-reunion character. In both the Greek and Italian censuses of 2001, the proportion of women in the total Albanian immigrant population reached 40\% (King 2003).

Carletto et al. (2004) and Stampini, Davis and Carletto (2004) have analysed data returns from the Albanian Living Standards Measurement Surveys (LSMS) of 2002 and 2003. The 2003 survey found that 55\% of Albanian households currently living in the country had one or more members who had engaged in international migration since 1990. Note that this measure of the impact and scale of emigration excludes entire households which have emigrated. According to the 2002 LSMS, a large share of the international migration flow consists of the adult children of current members still residing in Albania. Almost half of the children who, at some point since 1990, no 
longer live with their parents, are living abroad: 'a number of almost exodus proportions' (Carletto et al. 2004: 10).

\section{Data and methods}

This paper reports an analysis of the human impact of outmigration on the elderly populations left behind in villages and other predominantly rural settlements, with data principally drawn from two field research projects:

- 34 semi-structured interviews carried out in towns and villages in northern and central-north Albania for a project funded by Oxfam GB. This project examined emigration from north Albania to the UK, in particular the developmental impact of remittances and return migration. The interviews were with 'residual households' which had members who had migrated to the UK; some households also had other emigrant members in Greece and Italy. These interviews were not specifically concerned with the issues of older people, but these matters emerged strongly in several of the accounts. These interviews were carried out in 2003. ${ }^{1}$

- 21 semi-structured interviews with individual or coupled older people in four villages in south-east Albania. All interviewees were selected specifically as older village residents with adult children and other family members currently living abroad. As with the first set of interviewees in north Albania, some of these households also had children and other immediate family members who had migrated internally to Tirana and other important towns. These interviews were carried out in 2004 and 2005. ${ }^{2}$

In both projects, most of the interviews were not with single individuals. Except for people who lived on their own, it proved difficult and impractical to interview individuals. Most interviews were with couples or, especially in the north, with larger family/household units. This had both advantages and disadvantages. The main disadvantage was the strong tendency for the male to act as the spokesperson for the couple or family group, reflecting gender power relationships typical of Albanian rural society. This 'scene-stealing' by the man ran the risk of silencing the female voice. Of course this in itself offers important insights into gender interactions operating in such families. But we should not over-exaggerate the impact of this on 
the field interviews. In most cases, the family interviews were conducted in a relaxed and good-humoured atmosphere with various family members, women and children included, chipping in. On the other hand, where just elderly individuals and couples were interviewed, some personal and disturbing themes were exposed, and the interviewees often became emotional, as we shall see. 3

In addition to the above two sets of interviews, we also occasionally draw on other interview material, including that assembled in the World Bank study on Poverty in Albania (De Soto et al. 2002), and interviews with Albanian migrants in the UK collected as part of the Oxfam study (King, Mai and Dalipaj 2003).

\section{Themes and questions}

Literature search confirms that few studies have been made of the links and relationships between transnational migrants and their non-migrating parents; this is particularly true as regards explorations of the inner or emic perspective of the older generation which remains in situ. Gerontological and family studies emphasise geographical proximity as a key variable in intergenerational support of ageing parents. Migration clearly ruptures this proximity, but this does not mean that migrant children necessarily 'desert' their parents or give up their obligations towards them; indeed, often quite the reverse is the case since the migration is partly motivated by the desire to provide for family members, including elderly parents.

In a case-study researched by Baldassar and Baldock (2000), where migrants had moved to the other side of the world (from a northern Italian rural town to Perth, Western Australia), the authors found evidence of regular return visits and extensive care-giving by the migrants for their distant parents; this caring extended long after settlement in the new country. Obviously, return visits are necessary for 'hands-on' caring, but remittances, gifts, letters, phone calls, family videos and long-distance participation in decisions around health and well-being all contribute to 'caring from a distance' (Baldassar and Baldock 2000: 63).

How relevant is this Italian case-study to our Albanian research? Certainly Baldassar and Baldock demonstrate that long-distance care practices can be maintained, even from very far away, and there is an obvious similarity in geographical setting, Italy being a near-neighbour to Albania. In other respects, however, there are notable differences. True, parts of rural northern Italy were still 
quite poor in the 1950s and 1960s, when most of the emigrants left for Australia, but it was nowhere near as economically distressed as Albania 30 years later. Moreover, the Italian emigrants, despite their humble rural backgrounds, prospered in Australia and so were able to accumulate the material resources to make regular returns and transfer some of their wealth to their aged parents, whom they wanted to be ben sistemati - well set-up and comfortable. In fact the standard of living in northern Italy is now on a par with Australia.

Furthermore, Italian emigration to Australia was well organised; above all, it was legal migration, so there was no hindrance to return visits back and forth. Again, conditions are different in Albania, not only in regard to the general standard of living - still one of the lowest in Europe - but also in respect of the freedom of migrants to come and go, or for older people resident in Albania to visit their children abroad. Many Albanian migrants are in a dubious legal situation in destination countries: they have often entered clandestinely, remain undocumented, and work in the black economy. This is especially the situation for Albanian emigrants in Greece and the UK (Baldwin-Edwards 2004; King, Mai and Dalipaj 2003: 38-53). Their undocumented status makes it difficult for them to return, especially insofar as they would then have to arrange - and pay for - another clandestine re-entry to the destination country, with a high risk of being caught by the police or border authorities. We shall provide further evidence for this point in due course.

The themes to be analysed in this paper were identified partly from those raised in the limited existing literature and partly from the authors' own knowledge of rural Albanian family dynamics over the post-communist transformation. 4 The research questions thus emerged via an iterative approach between the two authors based both on prior knowledge and experience and on the exercise of planning the interview schedule. But these interviews were also structured in a very open way in order to allow the informants themselves to say what was important to them.

The account which follows is structured into several parts, representing the key issues in the phenomenology of Albanian migration, particularly as regards crossgenerational relations between migrants and their elderly relatives. We examine, largely through the voices of the interviewees, the socio-economic conditions giving rise to emigration in the first place; the main types of impact that migration has on older people who remain in Albania; care across borders; and the relatively recent 
phenomenon of 'migrant grandparents', whereby older parents follow their children abroad. Each section begins with relevant socio-economic, demographic and political background. The concluding discussion summarises our main findings and links them to important questions of policy.

\section{Stories of emigration}

Given the chaotic economic conditions surrounding Albania's uneasy transition to democracy in the early 1990s, most migration was economically motivated. Migrating abroad, even as an undocumented migrant, was seen as an economic imperative to escape poverty. This principal causal link is confirmed both in the World Bank's detailed qualitative study of poverty and migration in Albania (De Soto et al. 2002: 39-47) and by other questionnaire and interview surveys (e.g. King, Mai and Dalipaj 2003; Kule et al. 2002). In these surveys, especially where they embody qualitative accounts from in-depth interviews, it becomes clear that the poverty alleviation rationale includes a strong commitment to support residual family members who remain in Albania, especially the older generations who have lost their jobs in the economic shock therapy of post-1990 liberal reform, or who are retired on tiny pensions (see interview quotes in King, Mai and Dalipaj 2003: 54-6)

If the economic rationale is overwhelming, it is not the only narrative of emigration from Albania. Two others emerged (Dalipaj 2005; King, Mai and Dalipaj 2003). One is a narrative of insecurity and violence. Especially in northern Albania, the revival of revenge killings, which had been suppressed during the communist era, has put some young men in danger of their lives. Emigration is seen as a way out of this problem. More generalised violence spread in early 1997 in the wake of a financial collapse of a system of corrupt pyramid savings schemes. This breakdown of civic life and law and order, which also accompanied the collapse of the first Berisha government, was especially widespread in the south where the army and police arms stores were looted (see Olsen 2000: 70-3).

The second narrative is one of personal freedom, for young people especially. Emigration, perhaps as a student, is seen as a route to self-realisation and as a means to escape a still-paternalistic, convention-bound society. Although, from the point of view of the departing young person, emigration may be seen as a self-liberating and 
counter-hegemonic act, it is accepted by the older generation because education is regarded as a means of self-improvement for the individual and the family.

The following interview extracts illustrate, in turn, the three key motives for emigration outlined above. The interviews are with Albanian migrants living in the UK (Dalipaj 2005: 49; King, Mai and Dalipaj 2003: 40).

We left Kukës seven years ago. There we lived in a shack, a sort of house made just to shelter us. What else could we do? We had no water, no electricity, no sewage, no prospects for the future (young woman, early 20s).

I left Albania in 2000 because killings were happening in the village I used to live in. My brothers-in-law were involved in a blood-feud. Insecurity and killings are based on the kanun [the Albanian medieval code of customary law]. Once the killing starts ... it will never end (man, late 20s).

I left because of the Albanian mentality about women ... particularly about the way women should behave according to age ... I mean, if a woman passes the age of marriage, which is about 20 years of age, you will get a lot of gossip about why you are not getting married, and this hurts ... (woman, late 20s).

Given the lack of legal entry routes abroad, most migrants endured both risk and hardship in their migration journeys. Again, the most powerful and direct testimonies come from the migrants themselves rather than their parents. ${ }^{5}$ Such journeys have been well documented in the existing literature (Dalipaj 2005: 50-67; King, Iosifides and Myrivili 1998; King, Mai and Dalipaj 2003: 42-6), where some very harrowing accounts may be found. For migrants entering neighbouring countries clandestinely, the two most frequented routes are on foot across the mountains into Greece, and by sea, in a smuggler's dinghy, to the south Italian coast. For those migrating on to the UK a further traumatic journey has to be made, hidden in the back of a lorry across the English Channel. Two examples suffice to give a flavour of these journeys of hope. 
In the first a male migrant describes his arduous journey with a group of friends in order to engage in seasonal agricultural work in Greece (from De Soto et al. 2002: 42).

We formed a group of villagers and departed on foot and walked for about six days. We slept wherever and whenever possible, avoiding places with snow and frost. We could hardly sleep for more than two hours for fear of freezing ... one guy almost froze to death ... In Greece we managed to find agricultural jobs. The employer set up a thatched roof and we slept there. We were paid 3,000 to 4,000 drachma per day [about \$8-10] ... Our costs were minimal, we bought only soap and bread ... Since I started this form of emigration, I have gone several times to Greece in March or April and returned in August ...

The second quote describes a young man's journey across Europe to the UK and points out the key role of relatives along the way (from King, Mai and Dalipaj 2003: 46):

I had no future there [in Albania], no job, no social life. Moreover, my town was very dangerous at that time ... First I went to work in Italy for a year, where I had relatives ... I went by speedboat ... It's better to live in Italy because it's a beautiful place, but it's better to work in the UK ... English people are nicer ... they are not so racist [towards Albanians] as in Italy ... In Italy they do not like Albanians at all ... Then I went to France and then Belgium by train. My cousins accommodated me in Belgium ... but I was alone on the trip to the UK. There were eight of us in the lorry. During the trip I heard how some people had tried up to 16 times to get to the UK by lorry ... We departed from Ostend ... When I arrived in England I phoned my relatives ... I was somewhere near London. My cousin told me how to take a taxi and go to a railway station to 
get a train to London ... He helped me settle down here (man, 20s, London).

\section{Impact of emigration on older people who remain}

This is the empirical heart of the paper. Here we describe the impact of outmigration on the areas of departure, starting with some general impressions and then moving on to the more personalised experiences and feelings of the older people who remain.

\section{General effects}

In 1995 the French geographer Michel Sivignon reported on the dramatic population and landscape changes observable in the hills and mountains of southern Albania consequent upon the recent mass emigration to Greece and elsewhere. In many areas, according to his observations, more than half the population had departed; agricultural land had been abandoned wholesale (Sivignon 1995). Ten years later not much has changed. There has been a little return migration, but many more new young people have also departed. The testimonies of village elders say it all.

This village [in northern Albania], which is inhabited by 1500 people, about 350 families, is a very isolated place, far up in the mountains ... life is very hard. Each family only has about 350 square metres to cultivate. Because of these living conditions - no water in the place, isolation, very uncertain electricity, the land not very fertile - many people have left the village. Usually it is young people of around 20 who leave first ... they go to Greece, Italy, also to the UK ... Overall there are more than 70 families in Italy and Greece ... Half of these young men left for economic reasons, while the other half left to escape revenge ... With democracy many old wounds reopened and many families decided to leave to escape the consequences. Usually, when families leave to escape revenge, they leave for good as all male members of the family might get killed ... about 18 families have left because of this ... 
Much the same picture is reported by this father of six emigrant children in northcentral Albania:

\begin{abstract}
How many people live in [name of small town] now? Well, I don't know about the whole of [town], but what I do know is that in my neighbourhood there used to be 25 families - now there are only five and I know for sure they will be leaving soon. If you go there now you would be shocked, only abandoned land and houses, nobody there, I mean nobody, everybody has gone.
\end{abstract}

The age- and sex-selective nature of emigration puts particular pressure on women left behind, for they bear additional burdens of family care and of looking after the house and the land. They are acutely aware of the heavy social costs for Albanian rural families and communities, and also of their own increased vulnerability and psychological stress. These two brief quotes, both from women in the southern half of Albania, sum up these issues (from De Soto et al. 2002: 46):

There are no weddings taking place in the village ... only funerals have occurred over the last three years ... We are all going to leave.

Emigration is a means to survive but it is causing a tragic end to Albanian families ... We all feel heartsick for our sons and consider emigration an irreparable wound caused by the difficult life we are living.

All over Albania the contradictory effects of emigration are the same: it is viewed as virtually the only option for economic survival and improvement, but the social price that has been paid is almost unbearable - separation of family members and the wrenching apart of family and community structures which hitherto had been the very fabric of Albanian society. Particularly in rural areas, emigration and internal migration also take away important elements of the community's service structure, notably teachers and medical personnel, with resultant declines in education and 
health provision, making life even more difficult for those who remain behind (De Soto et al. 2002: 47).

At the macro level, annual remittances have grown from \$275 million in 1993 to $\$ 1$ billion in 2004, according to Bank of Albania estimates. Throughout this period, remittances have contributed 15-20\% of GDP and have equated, on average, twice the value of exports (King 2005: 149). The 2004 remittance flow represented an average of $\$ 1000$ per emigrant and more than $\$ 300$ per capita of the resident Albanian population, amongst the highest rates in the world. At the household level, earning remittances marks the crucial divide between poverty and being able to attain a tolerable material standard of living. In the simple words of one of the interviewees in the World Bank poverty study: 'A poor family is one that does not have a member who can migrate abroad' (De Soto et al. 2002: 39).

According to various surveys and estimates of remittance use in Albania reviewed by King and Vullnetari (2003: 46-9), the following categories of spending and investment can be listed, in approximate order of priority:

- day-to-day survival needs of the family - food, clothing etc.,

- furniture and consumer durables such as TV set, washing machine etc.,

- improvements in the dwelling - piped water, inside toilet, new roof, extra rooms etc.,

- maintenance and recovery of life-stage cultural practices, such as baptisms, weddings and funerals, and

- investment in business enterprises such as farming, small building firms, shops, a taxi etc.

To quote one sample survey of 694 Albanian households receiving remittances (Kule et al. 2002), more than half the remittance income was consumed by the family, $23 \%$ was saved, $7 \%$ was invested in property, $5 \%$ invested in a commercial enterprise, only $1 \%$ invested in a production-related business, and only $1 \%$ in farming. Nicholson (2001; 2004) provides case-study evidence for small-scale business development in a relatively prosperous lowland district of southern Albania, but it is not clear how widespread this phenomenon of 'productive return' is: our own impression is that it is rather localised. 
With guaranteed employment in state-run enterprises a thing of the past, the rural, upland areas of Albania have had their economic lifeblood taken away. Most state-owned industries have simply closed down, and a chaotic land reform left most rural households with tiny, fragmented holdings distributed from the former state farms and cooperatives. With the removal and collapse of agricultural infrastructure, including organised market outlets and irrigation systems, farming has not been able to act as a development impulse for rural areas, especially with most younger males having emigrated, leaving an ageing and increasingly feminised residual workforce. The farming that remains in highland Albania is subsistence, geared to household and local needs. Marketing and distribution systems hardly exist and most shops stock imported foodstuffs from neighbouring countries (De Soto et al. 2002: 19-28).

\section{Orphan pensioners, economic insecurity and split families}

The ambiguous nature of the Albanian migratory experience sees economic survival traded for social support within the family context. Older people become isolated because all or most of their children have migrated, either abroad or internally. This loneliness is especially widespread in the rural, highland areas where outmigration has been heaviest, and where geographical factors such as rugged topography, dispersed settlements and harsh winter climate exacerbate peripherality and isolation. The 2005 Human Development Report for Albania confirms that elderly people living alone and at high risk of social abandonment constitute one of the most vulnerable social groups in Albania (UNDP 2005: 54-5). Often children are not able to help their elderly parents at difficult times, such as illness or depression, because, as so-called illegal immigrants, they are not free to come and go when they want or need to travel. This reinforces even further the sense of depression and abandonment many older people feel, giving rise to what has been termed the 'orphan pensioners' syndrome (cf. De Soto et al. 2002: 46). These are some of the individual and familyrelated issues we deal with below, drawing on the interview narratives collected in the two regions of fieldwork.

First, the pension situation. The pension age in Albania is 65 for men and 60 for women. But pensions are very low and, for the cohort studied in this paper, mainly derive from work done under the communist economic system prior to 1990. Since there was no private sector at that time, these pensions are either for contributions to 
state entities or to the cooperatives. Most people used to work in the cooperative and now receive what is known as a 'cooperative pension'. Those who used to work for state institutions or enterprises receive the 'state pension', which is usually at least double the cooperative one $-\$ 40-80$ per month as against $\$ 20-30$. Even when there are two pensions in the family, it is very difficult to survive on this income only, considering the rapid price inflation that has occurred in Albania since the end of communism. All interviewees concurred on this. Two typical quotes:

I have a pension of 5000 lek $(\$ 50)$ a month. That is not enough, I have no other money coming in ... I have a son here in Albania who is financially independent from me ... I have another son in England, I just tell him I have no money left ... he has sent me what he could (man, 6os, north Albania).

One cannot look after the household with only 2700 lek a month (\$27) ... If a group of family members came to visit for a special occasion, this amount would barely be enough for one day ... (man, 70s, south Albania).

The purchasing power of pensions has been severely eroded by the high cost of food and other goods in Albania, a reflection of the fact that so much produce is imported. One couple's son, who lives in the United States, was surprised to find out, during a visit, that some food prices were higher in Korçë than in Chicago. Another couple were having to forego eating meat, which was expensive to buy, because they had just spent $\$ 200$ buying fuel for the winter.

Clearly, on the basis of this evidence, surviving on a pension is hardly possible. Two other sources of income thus become vital - remittances, and other sources of income and sustenance available locally, mainly cultivating the land. Remittances are an indispensable source of income, especially for those who do not even get a pension. Although the role of remittances in development is a contested issue amongst scholars, ${ }^{6}$ their primary use for the survival of households in Albania is widely accepted. Evidence on the role of remittances in different parts of Albania is 
presented in some detail in King, Mai and Dalipaj (2003: 54-9, 71-86), so here we just make a summary of key points.

Remittances sent to elderly parents by their adult migrant children depend on several factors, the most important of which are earnings, country of destination, legal or illegal status and the migrants' own family situation (i.e. whether they are married and have children). Migrants tend to remit more when they are single or, if married, if they migrate alone. Once they marry and have their own children with them abroad, remittances to their parents back in the village decrease sharply. Remittances are also highly gendered. When a woman marries and migrates, she becomes part of her husband's parental family and so remittances from her own work abroad tend to be channelled to her husband's parents, not her own. Moreover, remittances are sent, received and deployed mainly, if not exclusively, by male family members.

We have daughters ... daughters have husbands. They send us money only if the husband agrees to it. If he doesn't, there is no money (woman, 6os, south Albania).

Particularly for unskilled migrants working in low-paid, casual and precarious jobs, earning a surplus for remittances can be a problem. Many of the respondents told of their children's hardships in trying to keep their head above water financially, especially in Greece.

Our eldest son works in a factory [in Greece] that manufactures electric stoves. He leaves for work at 5 in the morning and comes home at 8 in the evening. And how much does he earn? $€_{30}$ a day ... That's not fair (man, 70s, south Albania).

The next two accounts exemplify the typical ways in which remittances are sent and used both for daily living expenses and improvement of living conditions. The second extract also illustrates how, in some households, several sources of income are integrated. 
They do not send the same every month; it depends on their problems and on ours too. In a year we normally get 200,00o lek (\$2000) and this is enough for us to live ... We also get a pension of 7,00o lek a month (\$70) - with this money we buy basic stuff, coffee, sugar and flour. With what we receive from abroad we first pay back the money we had to borrow ... and then we buy furniture and clothes. That's it (man, 6os, north Albania).

We don't live only on the money they send us from abroad. I also have my pension, which is a good one ... because I was an officer for many years. My daughter-in-law works as well, she's a nurse at a nearby hospital ... the two grandsons are in the UK, then my son is a mechanic here in [name of town] ... I mean, if you add all these things together, that is how you can live (man, 70s, north-central Albania).

Extending farming beyond subsistence production is problematic in Albania, because the products can often only be sold, if at all, under cost price. The lack of organised marketing structures, noted earlier, obviously hampers the situation. Furthermore, retired persons of this generation have to struggle with the concept and practices of the market economy, especially when their children, who might be more familiar with market principles, are not there to help them. It is not easy to adjust to this, after a lifetime of living in a centralised economy and society where everything was planned and looked after (not always to good effect) by the state and its various apparatuses. Liberal trade agreements with neighbouring countries bring in agricultural products at low prices. The Albanian farmer, who has only small plots and no mechanical equipment, cannot compete. For these elderly people, working in the garden plot around the house and perhaps also in the fields to gather enough wheat to make bread, enables them to cover some basic food needs. It does not allow them to sell anything at a reasonable price in order to make a profit. In the words of a 70 year old farmholder in south Albania: 
Our produce does not sell. For example produce comes here from every foreign country, from the Greeks, from the Italians, from Macedonia and from everywhere. Thus our produce ... is left in piles ... For example, if you look here, we have about 300 apple trees in this orchard. But I don't have security, I am not sure I can sell my produce. There are no marketing firms or the state that can provide such security, and so I have no guarantee that I will sell my produce ... I sell it at the mercy of luck, to individual traders ... [who are] ... interested in buying it for less money ... So you don't have security.

In the above quotation, '(in)security' is a frequently-used word; in fact, for most older Albanians, it is the word of the past decade or more. They feel insecure about their future, about selling their products and earning the value of the work they have put in, insecure about the very land they live and work on, and about what they see with some justification - as a corrupt and ineffective Albanian government, which they allege has forgotten them. The previous interviewee continues:

... the 'third-aged', as we call the retired persons, have been put last. In other words the retired are considered as being here in the now but not being here tomorrow. Let's give them whatever we can give them, so they can survive as best they can ...

But the biggest insecurity surrounds the future of their family structures which have been brusquely split by the necessity of the younger generation to migrate. The economic problems of older people, particularly those who receive regular remittances, are considered by many interviewees to be secondary to those surrounding the recomposition of the family.

Herein lies another paradox of the Albanian migration scenario. Older people are extremely keen for their adult children to get married, start their own families and thus ensure the future of the lineage (see the quotes in King, Mai and Dalipaj 2003: 66, 88-9). But as soon as new families are formed according to this generalised wish, remittances slow to a trickle and the newly-formed family has to consider where is 
best to bring up the next generation - the grandchildren of our interviewees. Objective analysis suggests this new, youngest generation will be better off long-term in the educational systems and job markets of the destination countries, not back in Albania. Hence the geographical split of the family across generations is likely to become total and more or less permanent. This is causing great distress for the older generations, for whom the inter-generational solidarity and compactness of families is traditionally overwhelmingly important.

\section{A difficult return}

The various structural problems noted above - economic, social, political - which still afflict life in Albania are important for the children of the interviewees when they weigh up the option of returning. Many retired persons have more or less reconciled themselves to the painful fact that their children will not return: quite apart from the economic difficulties of creating a decent livelihood in Albania there is also the reality that their children have settled down in their respective host countries. Other interviewees express a more ambivalent view - a kind of 'myth of their children's return' (cf. Anwar 1979). They hope that their children will return, and lay plans accordingly; but at the same time they also acknowledge that, both from an economic point of view, and because emigration brings cultural change amongst their children (not to mention the birth and schooling of their grandchildren abroad), return may never happen.

Typical of the hoped-for return is the following interview exchange which reflects the traditional extended-family expectation of sons' marriage and co-residence with the parents. Family houses are extended - often by adding extra floors - and new dwellings built, financed by remittances, precisely with this plan in mind.

Interviewer: Why is this place so large?

Elderly father: Do you think it is too big?

Interviewer: Well, I would have thought a whole floor would be enough for you.

Father: Yes, but the other two floors are for my sons, who live in the UK ... When they get married they will come to live here and 
open a business. They want to open their own restaurant, or a shop, and be self-employed.

It is important to be precise about where the return will take place to, for the map of economic opportunities for returned migrants (and all Albanians) is sharply differentiated spatially. In the now-depopulated hills and mountains of the far north and far south there are almost no prospects for returnees, beyond rejoining and looking after their parents and engaging in subsistence farming. Better opportunities are available in the Tirana region - the fast-growing economic core of the country and in other important towns such as Shkodër in the north and Korçë in the south. It is relevant to note that the above conversation took place on the outskirts of Tirana, where the northern-origin residual household had migrated at the same time as the emigrant sons had been in the UK. The large-scale internal migration of north Albanians to the Tirana area was mentioned early in the paper. Here, then, we see evidence of a multiple migration strategy with an intermixing of internal and international migration. In order to escape the harsh socio-economic conditions of the northern mountains, sons migrate abroad whilst the residual household relocates to the periphery of Tirana, where many hastily-built new districts have proliferated. Although these unplanned peri-urban developments have their own problems (lack of services, muddy roads, dislocation from the city itself), they are seen as more viable places from which to develop better livelihoods because of the proximity to the capital and the possibilities to open a small business or trade (for more discussion on this see Dalipaj 2005: 110-4).

Further examples of an ambivalent perception of their children's return are revealed in the following pair of interview clips:

Well of course I would like them to come home, but I don't think they ever will ... In the end I think only my husband and I will be left here (woman, 50s, north Albania).

... Even the youngest [referring to the grandson] when he left [for Australia] said: ‘don't worry, granny, I won't stay more than five or six years, I will come back, we just need to make some money so 
that we don't stay here [in the village] but can move to Tirana or somewhere else'. But I don't know what they are really going to do ... Refik [her son] does not plan to stay abroad, my dear. But I don't know, I don't know ... When he left he told me: give me permission mother because I will not stay [away] ... because you are getting older now, I will not leave you alone ... Will he come back? (widow, early 8os, southern Albania).

The latter quote is especially interesting because it presents the ambivalent views of one of one of the oldest interviewees, who lives on her own; and the migrations of her children are quite diverse, although not untypical. A few more details. Qazime (not her real name) has two sons and a daughter, all married. The daughter lives with her husband and children in a nearby village, having moved there to join her husband's family according to the virilocal Albanian custom. The youngest son moved to Elbasan, an industrial town in central Albania, in the 1970s and has lived there ever since. The eldest son has migrated to Australia (his wife's father had worked there in pre-communist times and had gained Australian citizenship). On the outside Qazime seems pretty convinced that they will return and that their reason for migration is only to accumulate some capital. But deep down (as the interview narrative suggests) she is not so sure. Qazime has visited her son in Elbasan from time to time, sometimes staying several months, and he has asked her to go and live there with him and his family. However, she feels she would not be able to live anywhere else but her own home in the village. Her daughter visits quite often and helps her cultivate her plot of land. Qazime receives a pension, remittances from her son in Australia, some assistance from her other son, and occasional small returns from the sale of agricultural produce. 7

Parents' growing realisation that their children do not want, or are not able, to return is matched by interviews with the migrants themselves amongst whom, if anything, the discourse of non-return is even stronger. In the first stage of the aforementioned Oxfam study, interviews were carried out with 26 Albanian migrants in the London area, most of whom came from northern Albania. Very few wanted to return; some feared that they might be repatriated because of their 'illegal' status in the eyes of the UK Home Office. The following interview extracts (from King, Mai and 
Dalipaj 2003: 53-6) illustrate various dimensions of the problematics of return from the point of view of young Albanians in this relatively new (for them) emigration destination country: the high levels of income and remittances that are attainable in London's booming economy; fear of deportation; the impossibility of visiting home whilst in an 'illegal' or provisional migration status; and the reluctance to return, except perhaps to Tirana.

Well, my status hasn't changed and I still don't know how long I am entitled to stay in this country ... I would love to get documents so that I could go and see my parents ... I don't want a temporary permit to work, I want proper papers, to come and go as I want ... I don't know how long I will be able to stay here ... if I knew, I would invest more money here ... or there, but to tell you the truth my parents keep telling me that the situation is worse than when I left ... I don't want to return ... for me to return everything would have to change, politics, the government, the economy, roads, electricity, water (man, 20s, London).

Yes, I help my family at home, I send them money so they don't have to worry about anything ... I don't care what they use it for. The most important thing is that my family is OK. So, every two months I send about $£ 2,000$. If I have to return I will buy a house in Tirana. Otherwise I will go to Albania only for holidays (man, early 20s, London).

'The sugar of the sugar is even sweeter': on grandparenting denied

With hopes of permanent return diminished, the continuing wish of the older generation is to see their children and grandchildren more often. Older Albanians would like greater freedom to be able to visit their family members abroad, and for the migrants to visit them in Albania. However, this has proved very difficult because of the restrictive migration policies and regulations in place across Europe. A further issue is how the regulations have been discretionally used and abused; the need to 
purchase expensive visas through corrupt consular staff is reported as a recurring problem.

For migrants from villages in south Albania, ease of access across the mountain passes to Greece is a vital component of their ability to support themselves and their parents by moving on a repeat basis to acquire temporary work in the latter country. Whilst this border has been relatively porous since the Albanian sentries relaxed their grip in 1990-91, the Greek authorities, for their part, have maintained a public policy of control and containment by patrolling the border itself and by periodic 'sweepingup' operations of undocumented Albanians in Greece. Fakiolas (2003: 537) has documented the massive scale of these repatriation measures, which sent back an annual average of 230,000 Albanians during the 1990s and early 2000s. ${ }^{8}$ And other writers have described the repressive brutality of the Greek police and army personnel towards Albanian immigrants (Baldwin-Edwards 2004; De Soto et al. 2002: 41-3; King, Mai and Dalipaj 2003: 50-1).

Burbuqe, one of our interviewees, described an attempt by her son and his cousin to cross the mountain frontier into Greece in the 1990s. The two young men were caught by the Greek army and she and her husband 'had to keep the two of them in bed and apply salt and onions to their injuries' (a traditional treatment for swollen wounds). Gazing tearfully at the high mountains from her village home in southern Albania, she said: 'When I look at those mountains over there ... I say to myself, how many times did my son walk across those heights?' Now the son lives with his wife in the US, where they emigrated five years ago via the Diversity Visa scheme, after having worked for several years in Greece. 9 Burbuqe's other son lives in Thessaloniki with his wife, where they have just had their first child. Burbuqe and her husband have never visited their children abroad, although both sons are able to visit them from time to time. The son in the US has visited twice, but as Burbuqe relates, these visits bring their own pain:

Every time they have come and gone, I have washed the road to Rinas [Albania's international airport] in tears ... When they left for the first time ... I can tell you that I felt I would not return home alive ... I would say to myself: son, when you come, take a little 
flower and bring it to my grave because I will not see you again ... I will never forget that (Burbuqe, early 6os, southern Albania).

As the holder of a Diversity Visa, Burbuqe's son can travel freely, although obviously distance and cost limit the frequency of such intercontinental return visits. For those in countries closer at hand, other barriers intervene.

Our son, the one who lives in the UK ... although the British state was very generous and helped him for two years, they gave him no papers and as a result I have not seen my son for five years. I have never met my grandchildren ... only if you have children working abroad can you understand what this means ... (man, 6os, north Albania).

And for migrants in Greece, the inefficient bureaucracy constitutes a frustrating stumbling-block to the ability to travel freely between neighbouring countries (see Psimmenos and Kassimati 2003). Ferit (early 70s, south Albania) has a son and daughter, both married and living in Greece:

... the children in Greece have not had the possibility to come [and visit] because they don't have proper documents ... They put the application in and it has been a very insecure process ... At times they apply and they are rejected, at times three or four months pass, they go there [to the offices] and they are told there is no response yet, every day like this. Even when their application has been accepted, they are told that the permit they have just received in their hand has already expired, and they have to start the process again ... [and] every time one applies, one has to pay ... So they can't come, because the Greek government does not give them proper documents.

The 'older old' are scared what might happen to them if they become ill with their children abroad; or even die without seeing them again. Xheviko, from south Albania, 
is a widow in her 7os; all her five children live away, three abroad (in France and Belgium) and two in Tirana.

I pray to God day and night, every time I go to bed I pray as I cover myself with the blanket. Oh God, grant me good health. Oh, God grant me good health. Oh God please, because I am alone.

Xheviko has not yet seen her youngest grandchild in France. She applied for a visitor's visa, but was refused without explanation. If anything it is this brutal separation from grandchildren that vexes older people most. The bond between grandparents and grandchildren is especially strong in Albania, where it is often said that older people love their grandchildren more than they do their children; 'the sugar of the sugar is even sweeter', the saying goes. Burbuqe, whom we quoted from extensively above, has not seen her new grandchild in Greece; she has only heard him gurgling over the phone. Blerim, from northern Albania, has never met his grandchildren in the UK:

My eyes are full of tears when I speak to the little ones on the phone ... I ask them how they know me as their grandpa - they know me from photos. When I can't sleep at night I kiss their pictures ... All my sons are abroad ... Every day we cry but we can't change things.

\section{Care across borders}

As noted earlier, transnational care amongst migrants has been little researched. Studies on inter-generational care-giving practices generally focus on female migrants and the care of their children who are left in the home country: this 'transnational mothering' has been researched by Zontini (2001; 2004) in the context of Filipina migrants in Italy and Spain and by Hondagneu-Sotelo and Avila (1997) for Latinas in the United States. Care of the elderly has been less often identified as a specific research focus, although research on return migration has often noted that the need to look after aged or ill parents is one of the triggers for return (King, Strachan and Mortimer 1983). 
Caring for the elderly is a strongly-felt duty in Albania. Traditionally, middle-aged and elderly parents will live with one of their sons, usually the youngest, and his wife. Indeed the youngest son is referred to as 'the son of old age' - djali i pleqërisë whose role it is to look after his parents in their later years. As such, sons' absences were lamented the most during the interviews, as sons are, in a sense, seen as social security for the future of parents. Similarly, to respect and care for one's parents is not only a duty, but regarded as highly honourable in Albanian society.

All of these issues were illustrated in interviews. In this first brief quote, from a father whose children live in Greece, the USA and Canada, there is no question of joining his daughter in the USA, even though she is in a better financial situation than her siblings:

Even if Rina [the daughter] were to tell us to come and stay ... we couldn't go. We have the tradition to live with the youngest son [who is in Canada] ... (man, late 6os, south Albania).

But what happens when parents only have daughters? According to the Albanian virilocal society, the place of the married daughter is firmly with the family of her husband: 'that's where her honour is', as one interviewee put it. In a way, it is easier for such parents to accept living alone, since 'that's how it's supposed to be' (man, 70 , father of five daughters and no sons). This interviewee went on to point out that, in a relative sense, he and his wife were less worse off than parents with sons who had emigrated and left them alone. Older parents with just daughters will probably prolong living on their own until one partner dies, which will then mean that joining a daughter's household becomes a matter of necessity. The wife of the man quoted immediately above put the dilemma in the following terms:

They all [the five daughters] tell us to go and live with them. They tell us to sell it all and stay these last few years we have left with them. But how can we go and live with the son-in-law? When one of us is left alone, then we'll have to. If I die, what will he do? Or if he dies, what will I do? 
In the Albanian context, the very act of migration can be seen as a form of concern for the family, since migration brings in much-needed income enabling the family to survive. For parents and children alike, migration and living far away from one another are considered necessary sacrifices in order to ensure a better life for the whole family. ${ }^{10}$ This was clearly expressed in the interviewees' narratives, which lamented their children's absence, yet appreciated that it would have been worse for the family as a unit had the children stayed in Albania: worse for the children because they would have no work and no future; and for their parents because they would be poverty-stricken and would see their children suffer and never get anywhere. These feelings and attitudes are generally mirrored in interviews with Albanians abroad, who realise both the inevitability of the need to migrate and their duty to send remittances to support their parents (see King, Mai and Dalipaj 2003: 38-59 for interviews in London).

Care across distance takes other forms. Besides remittances, children are regularly in contact with their families by mobile phone. Every interviewee mentioned the fact that their children speak to them at least once a week. However, the length and frequency of the calls depend on the economic situation of the children, since they are the ones who call. If the parents need to speak to their migrant children urgently, they make a brief call, and the son or daughter then calls back. Visits demonstrate even more that children care for their parents, and also that they are successful migrants. But such visits may be blocked or limited by the migrant's 'illegal' status and by the cost of the trip, as noted. Visits by fellow-migrants are also part of the care, particularly when the children cannot come to visit themselves. Such visits may be important for conveying cash remittances and presents.

Some of the interviewees found it difficult to talk about their children's visits, especially when they had been infrequent. Burbuqe's memorable phrase, 'I have washed the road to Rinas Airport in tears', when returning from seeing off her son to America, takes on an almost iconic status. In a more general sense, some parents feel that not having their children there in the house, where they 'belong', to care for them in their old age, or even just to enjoy what is regarded as a 'normal' family life, is something that they can hardly cope with. In the following narrative extracts, this sense of abandonment, almost of grieving for a 'lost' loved-one, is palpable. Ferit and Mynefe talk about their situation: 
Mynefe: ... we have had many hard times. For us, at our age, not to have a grandchild here, or a son, or a daughter-in-law ...

Ferit: so that they can take care of everyday tasks ... I got married, I had children ... when I had my children, I was capable ... me and my wife were young. Now we are at this old age of 70 years and she at 64 years old, not to have a child, or a daughter-in-law, a son, a grandson, a granddaughter, to ask them to do something for you, to ask them to fetch you water, or food, or this or that. You have to manage on your own ... in other words it's a difficult life, a life, how can you call it, monotonous, without having children around. You can see ... we have all this house, both of us, husband and wife ... but the house is closed, empty [trembling voice, tries not to cry] ...there is no activity, there are no people to dwell here.

Others felt the same:

... and I raised him, so that I could have my son now at this age. I want my son to come to me not to leave me ... I don't need money, I want my son to come home. How can you leave these old people on the street? (woman, 8os, south Albania).

I told him [her son] ... photographs and video-tapes are not good enough for me. I want to see the original, I want to see you come through the door ...(woman, 6os, south Albania).

It is important to appreciate that these cris de cœur are not simple expressions of selfishness on the part of older people. Being cared for is closely linked to caring for, particularly in rural Albania. The relationship is reciprocal. All the respondents regretted that they were missing out on time spent with children and grandchildren and were not able to give them a hand with family obligations, render parental advice and fulfil their respected role and duty as 'senior citizens' within the multigenerational family setting. Above all they bemoaned the fact that they could not play their role as grandparents, and look after the grandchildren. ${ }^{11}$ As noted above 
Burbuqe and her husband Serjan had just become grandparents for the first time: he was born in Greece a few days before the interview. Burbuqe had not seen him but only heard his sounds over the phone. Such an important family event should have been experienced together as a family, but the new grandparents had not been able to obtain visas to enter Greece. For other grandparents, however, another possibility opens up to deal with the painful separation: to join their children in migration.

\section{'Migrating grannies'}

As migrants settle down abroad, regularise their status (especially in Italy and Greece where there have been periodic regularisations of undocumented immigrants - in Italy in 1995, 1998, and 2002, in Greece in 1998 and 2001), and establish their own families in the destination countries, their likelihood of return diminishes. This prompts another migration possibility: a phenomenon referred to colloquially in Albania as 'migrating grannies'.

Two important preliminary statements about this new trend. First, the fieldwork, interviewing in Albania, did not allow us to 'capture' this process very well, since the persons involved are obviously likely to be abroad. However, we were able to get some handle on the phenomenon by talking to people who knew other people who had followed their children's migratory paths; to those who were considering or, indeed, actually preparing to leave; and to those who had been and come back. The second general remark is that this is a migratory option usually taken by the 'younger old' rather than the 'older old' - by people in their 50s and early 6os rather than those in their 70 s or 80 .

The conventional view in the migration age-cohort literature is that migration at a mature or advanced age is a risky business. Although there is a danger of ageism in these generalisations, the impression is that older-age migration poses greater problems of adaptability to a new environment (including language-learning), and greater vulnerability to health issues, compared to migration as young adults. Because of their lack of residential history in the destination country, older migrants may fall foul of legalistic regulations on cross-national entitlement to citizenship and welfare (Ackers and Dwyer 2002; 2004).

Existing literature both validates and challenges these generalisations. The wellknown phenomenon of international retirement migration, for instance, has 
demonstrated how wealthy North Europeans who retire to the sunny climes of the Mediterranean often gain a new lease of life and enjoy a healthier and more sociable old age in the warmer temperatures and more relaxed atmosphere of retirement locations which may also be holiday resorts. However, this literature also throws up evidence of more problematic outcomes - cases of loneliness away from children and family, of sudden health problems, or the death of a partner, of alcoholism, and of failure to 'integrate' or to learn the local language. The rather abundant literature on North Europeans settling in Spain and elsewhere in Southern Europe provides plenty of insights into these various outcomes (Casado-Díaz, Kaiser and Warnes 2004; King, Warnes and Williams 2000; O'Reilly 2000; Rodríguez, Fernández-Mayoralas and Rojo 1998).

It is also the case that a good deal of this lifestyle and environmentally-motivated retirement migration is channelled by family links: older people are migrating to countries where their adult children are already settled. Extended families are recomposed abroad, and grandparents can be near to their children and grandchildren. This is certainly the case for a share of the older-age British migration to southern Spain, Australia and North America (Warnes 2001).

Parts of the Albanian context show parallels with these more affluent elderly migrations briefly described above; other aspects of the Albanian experience are very different. There are obvious similarities in wishing to reunite the family and see children and grandchildren on a regular basis. But there is also a more instrumental economic rationale operating in the Albanian case: healthy and active grandparents can take on childcare duties, freeing the children's mother to go out and work, thereby doubling the earning capacity of the emigrant household. Of course some of the additional income will be defrayed by the extra costs of food and accommodation, but generally the economic calculus of a dual-income migrant household makes sense. Rather than marking time at home on their own - see the interview dialogue with Mynefe and Ferit above - the grandparents feel that they can be of practical, economic use to their children, receive care themselves as and when they need it, and feel above all that they are fulfilling part of their customary and ordained duties as grandparents.

As stated, our field evidence on grandparent migration is fragmentary. Hence we will focus on a few case-studies, teasing out the various options facing older people 
who have all or most of their children settled abroad. Regarding older-age migration that has already happened, our information and general knowledge of the Albanian immigration situation in a number of countries, especially Italy and Greece (for example King and Mai 2004), confirm that this is a process that is gathering adherents. One trigger for emigration is sometimes the death of the husband (usually the older of the two marriage partners); as a result of which his widow, if in good health and otherwise willing and able, may well join a son or daughter abroad. Some evidence for a general propensity for older females to migrate than older males is provided by the 2001 Census where there are $10 \%$ more males than females in the 6os age cohort (INSTAT 2002: 28-30).

One south Albanian couple - Selami and Pranvera - were preparing for emigration to the United States at the time of the interview. The couple are farmers in their 50s and have two daughters and a son. In the early 1990s Selami and the son made a number of seasonal migration trips to work in Greece; from the proceeds of this temporary migrant labour the family was able to renovate the house and finance important family events such as funerals of elderly relatives and the weddings of their two daughters. Both daughters, who have some tertiary education, were successful in the Diversity Visa (DV) lottery for emigration to the United States; and both married in Albania before emigrating with their husbands. Now they are both settled there, working and having grandchildren. Meanwhile the son, after his early Greek emigration episodes with his father, has a job in Albania with the public administration; he too is married with children.

Selami has already been to the States for eight months when the first of the daughters was there. Selami and Pranvera are now in the process of family reunification with their eldest daughter. Both daughters have professional jobs in American and work very hard, as do their husbands..$^{12}$ The plan is for Pranvera to look after the grandchildren, which will include making sure they speak Albanian. By migrating to the US to join their children, they are fulfilling their longing to be grandparents in the full, 'hands-on' sense of the term. Pranvera will also cook and clean for her daughter's household. In this case, then, the care-giving is reversed: rather than adult migrant children caring for their parents 'back home', the middleaged parents follow their children to care for them and their children. Here is an excerpt from Pranvera's interview: 
God willing the documents will come, so we can be together ... we can help our children, and for ourselves as well ... I want to go there so I can help them, support them, so that my daughters can be better-off financially. And also to teach them [referring to the grandchildren] Albanian, because they have forgotten Albanian, the girl doesn't know it at all ... We are not able to speak with the girl on the phone ... just bye bye, mummy, daddy, that's all ... They [her daughters] don't have time [to teach them] because they are busy at work. What little time they have at home they have their own duties, washing, cooking ...

Pranvera is one of the lucky few able to exercise choice and be with their children abroad, although, intriguingly, we hear little about how Selami will fill his time in the United States. ${ }^{13}$ Family reunification, or even a visitor's visa, still remain the dream for many other grandparents; grandmothers, in particular, desperately want to be with their daughters when they are having children and need extra support. Being with their sons and daughters for such important events, and perhaps to stay longer, is almost entirely dependent on the legal status of the children in the destination countries. In general, those who benefited from the US DV programme, the Canadian Highly Skilled migrant programme, or those who have regularised their stay in the destination country have been able to facilitate immigration visas or long-term tourist visas of up to a year for close family members.

Sali and Sanie (south Albania, he early 70s, she late 6os) were beneficiaries of such a long-term tourist visa. Their story reveals further interesting aspects of the management of care and grandparenting across long distances. The couple, who live on their own, have two sons and a daughter, all married. The sons live in the US with their families, whereas the daughter lives in a nearby village. Their income derives from several sources: their pensions, some farming, remittances from their sons, and additional help from their daughter. Their sons migrated for reasons of economic hardship and personal insecurity following political harassment. One son went via the DV scheme, the other entered via Cuba and Mexico. Both are now settled in the US and have created their families there. However, in both cases, only the sons were able to work, whilst the daughters-in-law looked after the home and the children. 
Using the one-year tourist visa, Sali and Sanie were able to stay with their sons, releasing their wives from childcare and household chores so they could access paid employment. During this period, one parent lived with the family of one son and the other with the other son's family, changing places halfway through. This was a difficult arrangement, as can be imagined, but it was a sacrifice designed to achieve concrete economic results, as well as allowing the grandparents to exercise their caring role. Back in Albania, they are now preparing their case for family reunification, so that they can continue to provide this care, at least until all the grandchildren are at school.

Many other grandparents can only obtain a short-stay single-entry visitor's visa. Fearing that it will be impossible for them to get another chance to visit, they may overstay these visas and thus enter 'illegality' in, and the risk of expulsion from, the country of destination. They are thus condemned to a potentially long exile, this time separated from their other children who might still be living in Albania.

We saw earlier how Xheviko was turned down when she applied for a visa to visit her children and grandchildren in France. No reason was given for the rejection. Moreover, the money she had paid out for the application was not refunded; it equated one month's pension. Others had similar problems trying to get visas to visit their children and families abroad. The situation had become particularly difficult for visiting Greece where a previous provision allowing parents to reunite with their legally-resident migrant children had recently been rescinded.

They keep you waiting for hours at the consulate, you have to give an interview - maybe they grant you one [a visa], maybe not. Maybe the papers are in order, maybe not. They put forward all sorts of excuses. So, it's very, very hard. It frustrates you and you think to yourself, to hell with this. And you lose the money that you've spent [to process the application] ... (man, 6os, south Albania).

... now they have stopped it [giving visas] altogether, particularly for elderly people, because they saw that everyone was going to their sons and didn't come back, and they [the Greek authorities] 
saw that and so don't grant visas anymore (woman, 6os, south Albania).

Overall, most informants felt they would like to be able to visit their children for limited periods of time rather than remaining abroad with them all their lives. Reasons given for this stance mainly focused on existing ties to 'home': they had their house in Albania, they were used to life in the village, and their friends and the rest of their extended families were there. A closer look at these reasons reveals interesting elements, some of which are specific to Albania. On the matter of the village house as the base for 'home', the interviewees are part of a generation which lived during hardship and poverty. All went through the harsh times of communism, and the older ones also experienced World War Two. They all witnessed the emigration of their children. Under such circumstances their rural homes remained their fixed point, guarded with almost fanatical loyalty and care. This was their investment during the difficult years of communism; now the house represents the 'sweat and blood' of their children, who have toiled abroad to improve it. As a result, the value of the family house goes beyond its monetary value. Also important is the surrounding network of relatives and friends in what are usually closely-knit villages and neighbourhoods. These networks are built on kinship, trust and a history of good neighbourly relations, often extending over generations. The relative or neighbour is the first place to go for assistance - for childcare, elderly care, keeping an eye on the place whilst the occupants are away, or as overflow accommodation during family rituals such as weddings and funerals. This is not to say that there are perfect relations with all neighbours but, because of spatial proximity, people go to great lengths to foster good neighbourly relations because of the mutually beneficial results. Often the neighbourhood will consist of several members of the same extended family, such as several brothers and their families living next to each other. Such an arrangement is not available in foreign destinations or in Albanian urban centres. These aspects mean that life at home, in their village, feels most comfortable. This is especially the case in the southern Albanian villages, where there is more of a sense of community. In the more rugged and remote north, where the settlement pattern is more dispersed and the 'village community' feel less evident, many residual migrant families had 
partially or wholly relocated to a larger urban centre such as Shkodër, Tirana or Durrës.

Some, as noted, had personal experiences of staying with their children abroad for various lengths of time, and often this was a factor in them actually deciding not to migrate. Ferit and Mynefe's joint interview revealed some typical reasons:

Ferit: ... we don't want to go and live there, in Greece ...

Mynefe: we cannot stay there.

Ferit: We don't like the life in Greece. We like our own country, our own home, our own people. We were born here, we will die here, we will live here ... We have seen some who have gone abroad, parents ...

Mynefe: but they have been left alone.

Ferit: When they have returned, they said they missed even the stones and the trees. Why? Because older people cannot adjust to migration. They will be staying indoors all day long, they don't know where to go, what to say, they don't speak the language ...

Mynefe: Greece is not for us. Like he [her husband] said, we were indoors there, we didn't speak the language, the children would go to work all day long, we couldn't really cope with staying there ...

Ferit: We went there twice for a month and we stayed twice for three months. I couldn't go out, the environment was dirty, cars, hot temperature, large population ... So we didn't go out. Only when the children came home from work, could we get together in the room. But they were tired ... so they would go to bed, because they had to get up early the next day for work ... We had no choice but to be by ourselves again. So it was not a pleasant time we had there. We only went there because our children did not have documents and could not come to visit us.

The story is much the same for some older people's attitude to internal migration, especially interviewees in the south. Qazime, who we met earlier in the paper, has one son in Australia, whom she hopes will return (but, as we saw, she is beginning to 
suspect he may not), and another son in Elbasan, a large town in central Albania. Although the second son has asked her to go and live with him, Qazime is defiant:

No, I won't go there, I couldn't stay there, indoors all day long ... Here [in the village], I go out, a little here, a little there. I have gone there [to Elbasan], I have stayed five, six weeks, two months. Then I got bored and didn't go there again. You stay indoors all day long, no one comes to visit or see you.

Dashamire, aged 75, had a similar experience. About five years ago she went to live with her youngest son's family in Korçë. She stayed there nine months but 'it seemed like 19 years'; so she returned to live in the village homestead.

So, for those who had been abroad or elsewhere in Albania to spend extended periods of time with their children, reactions varied, according partly to their age and adaptability, the latter dependent in turn on education and their own prior experience of mobility. One older migrant, who had spent a year with his son's family in Chicago, described how he filled his day taking his young grandchildren to the local park or to the swimming-pool; but his wife was less happy, spending most of her spare time indoors watching Albanian videos. Another 'returnee' referred to the fact that, in America, his freedom to just 'go out' was limited by complete dependence on his son's car, which he could not drive. In yet another case, the elderly father had been able to make use of a bicycle to visit the surroundings of his new 'home' in Toronto, and make friends at the Albanian city mosque, while his wife was looking after the grandchildren at home. Clearly, the decision, for those who are in a position to exercise choice, is between two very different worlds and lifestyles: remaining alone and separated from children in the home village where they have lived all their lives, or joining their children in an unfamiliar big city (Athens, Milan, London, or in North America). A 'middle way' would be to achieve some kind of transnational mix and be able to choose to spend variable amounts of time in each place. In one interviewee's words: 'we cannot stay there [in the US] for good. Five, six months there, five-six months here, it's better. Not forever'. This pattern might be attractive but is not easily achievable for reasons of cost and legal barriers to such movement. 
For the latter to be removed, there needs to be a change in migration policy and attitudes in the destination countries.

\section{Discussion and recommendations}

Here we summarise our main findings and, from them, draw out some policy implications and recommendations. Key social problems arising from Albania's ageand gender-specific outmigration are family separations and semi-abandonment of older people. The interviews offered many narrated examples of these issues. Within the context of the massive scale of rural outmigration, the most serious social problem concerns older people who have 'lost' their on-site family and social support. Although Albanian custom obliges the youngest son and his wife to take care of his parents in their old age, emigration is breaking down this tradition. Left by their emigrant children and with declining social support and pensions in the 'new' Albania, many older people, especially in isolated rural areas, are feeling depressed and are worried about their abilities to fend for themselves (King, Mai and Dalipaj 2003: 97).

Of course, emigration yields remittances, at least for a time, and these are often crucially important in ensuring a minimal level of economic well-being. But Albania's older residents are used to being frugal, after their experience of austerity under communism, and are nowhere near as consumerist as the younger generations, especially those who have reached adulthood after 1990. Therefore, for many older parents, remittances are not so very important, and cannot compensate for what are seen as the normal and therefore irreplaceable privileges and duties of old age, which are above all connected to grandparenting and the physical proximity of the family. Meanwhile, on the part of most migrants, the sense of filial responsibility is still strong, and certain kinds of long-distance care - material help, emotional support through telephone calls and 'hands-on' assistance on return visits when these are possible - are indeed effected, as our interviewees' testimonies have shown.14 Moreover other relatives, and friends and neighbours in the village, are also able to supply a network of social contacts and help when needed, whether for personal care or help on the farm; this was especially apparent in the villages of southern Albania, less so in the more socially fragmented setting of the rural north. 
The massive scale and demographic selectivity of the Albanian rural exodus has left older people especially vulnerable because, in many cases, all their children have emigrated. This differentiates the Albanian case from the Italian one cited earlier (Baldassar and Baldock 2000) where the incidence of emigration was less widespread, so that there were often other siblings around to help with old-age care (for more ethnographic depth to this see Baldassar 2001), and where the standard of living and social welfare provision improved enormously over the period since emigration took place.

From a policy and humanitarian perspective, the key finding of the research presented in this paper is the way in which restrictions on mobility and migrants' rights - to travel, to reunite, to easily acquire visas - are creating real problems for migrants and their elderly parents. Schisms are drawn through families, and the 'normal' cross-generational, and often reciprocal, supply of care and family solidarity is arbitrarily blocked, to the detriment of older people who are bureaucratically, as well as physically, isolated from their migrant children. The recommendations presented below are no more and no less than what the interviewees want from the country's politicians and others who hold power at policy-making levels in Athens, Rome, London and Brussels.

First, there has to be support for the elderly and their migrant children from the Albanian government. Older people understand that their pensions are low because the Albanian state is not rich. On the other hand they observe lavish spending on the personal whims of allegedly corrupt political elites. So they feel that their country's leaders should:

- be more responsible, committed, transparent, and listen to the concerns of the voters;

- ensure economic stability in order to create job opportunities for the children back in Albania;

- support better the cohort of people who have been unable to cope with, or have been victims of, the transition to the market economy;

- provide more care for retired people, such as food concessions and environments for social activities; 
- work with destination countries towards a more open, regular and hassle-free movement of people, particularly older migrants who want to be with their families;

- institute proper legal and social protection for migrants and their families.

The Albanian government's attitude regarding these issues has been passive for a long time; the recently-published (end of 2004) National Strategy on Migration (Government of Albania 2004) is but a first step. Instead the main reaction of the Albanian authorities in recent years has been to respond to the needs and fears of EU countries, particularly neighbouring Italy and Greece, by increasingly policing its own borders - a veering back to the communist era when the borders were sealed around the Albanian gulag. With the carrot and stick of development funds and entry into the $\mathrm{EU}$, these neighbouring countries have been able to force their agendas onto Albania with considerable success: witness the confiscation and destruction of the fleet of speedboats in Vlorë that gave Albanians access to Italy and the much tighter patrolling of the Greek border in recent years.

Second, the governments of migrants' destination countries can and should do more to improve the quality of life for migrants and their retired parents. Interviewees understand the power of these governments and the potential they hold for action and change. If only they and their children could have easier opportunities to visit each other, their human situation would be much improved. Visits have both a social, caring nature and are also deeply symbolic; they illustrate how respectful a child, especially a son, is for his parents, and how successful he is in his migration project. As such, restrictive migration policies and regulations are not only harmful in a simple emotional sense, they also destroy social relations and norms back in the country of origin. They impact directly on the very status one has in the community, which can be of vital importance for a dignified life.

From the point of view of benefits to the country of destination, elderly migrating parents should not be considered a burden but an asset. They are providing muchneeded care services which might otherwise be shouldered by the state; this mitigates competition for childcare services between (legal) migrants and local families; and it releases another worker to be productive in the local labour market, to the potential benefit of the host society. 
Accordingly, interviewees would request destination governments to do the following:

- Eliminate the stringent visa regime they now have for older visiting relatives, and institute instead a procedure - perhaps under special regulations for this particular group of people - whereby the visitor need only show their passport to gain entry.

- Charge only a symbolic amount for processing visa or entry-permit applications for the elderly and make the process affordable and accessible. Multiple-entry visas should be issued instead of single-entry ones. The visa policy in place works against temporary visits and actually leads to overstaying which, in turn, causes visas to be even more restricted. Consequently a vicious cycle is created and maintained as a result of poor policy.

- Ensure that visa procedures are fair and equitable and not used as a political weapon or a tool of discrimination against the poor and the powerless. This implies that migrants in these countries should be equipped with proper permits to stay and to work, with efficient, low-cost procedures for the issuance of such permits.

\section{Conclusion}

The evidence presented in this article constitutes, we venture to claim, a remarkable and even unique picture of certain aspects of a little-known society undergoing extremely rapid transformation. This 'late window' on a peripheral part of excommunist south-east Europe reveals a process long forgotten in north-west Europe, but now very active in other poor countries of the world where emigration is seen as a route to survival. Two dimensions of change have been dominant in framing our Albanian analysis:

- the swift transformation from a centrally-planned economy and society based on agricultural and (less so) industrial production and on employment and welfare for all to an economy based on neoliberal principles in which social polarisation has become acute and where many productive facilities have simply closed down; 
- the massive scale of emigration after 1990 which, by 2004, had seen one quarter of the Albanian population, in particular young adults, living abroad.

This emigration, together with large-scale internal migration to towns and cities, was a necessary response to the chaotic process of economic and political upheaval which characterised the post-communist period, but which in turn provoked its own social dislocation in terms of impact on family structures and, especially, older people. The transitional cohort of older people who are the main focus of this paper are caught up in, but ultimately marginalised by, the whirlpool of political, economic, social and migration-related changes which transformed Albania during the 1990s. Having lived most of their lives under the control-freakery and propagandistic myths of Enver Hoxha's 'perfect communist society', with virtually no contact with the outside world and no outlet for private initiative, they were ill-prepared for the destructive (as well as creative) forces of the market economy, or for the possibilities and hardships of clandestine emigration. For the older generation there is a recurrent theme: economic survival has been bought at a high price - increased vulnerability and the danger of social abandonment. Although we have stressed the impact of ruptured family systems and consequent loneliness on the lives of older people 'left behind' by their sons and daughters, we should acknowledge the difficulties for the emigration cohort too - their struggle in countries that profit from their labour but often reject them as 'illegal immigrants', and their psychological strains and moral dilemmas in trying to balance their own life chances with a sense of filial duty to their parents. What makes the whole cross-generational care scenario so difficult is the international migration control regime within which the Albanian migration drama has been played out. For, with the exception of a few thousand migrants who were given emergency refugee status in Italy in early 1991, most of the million or so emigrants have moved abroad in some kind of clandestine fashion. Whilst large numbers have subsequently had the opportunity to become regularised, ongoing difficulties have hampered the ability of many (including their elderly parents) to come and go as they would want, in order to link up as 'normal' families and in order to deliver the care and support that older people expect and deserve. 


\section{Acknowledgements}

An earlier version of this paper was presented to the International Geographical Union's Commission on Global Change and Human Mobility at their International Congress on 'The Spatial Impact of Human Mobility in the Mediterranean Region', Pescara, Italy, 2-3 December 2005. We thank Mirela Dalipaj and Nicola Mai, who carried out most of the interviews in northern Albania, and Tony Warnes for helpful suggestions for improving the paper.

\section{References}

Ackers, L. and Dwyer, P. 2002. Senior Citizenship? Retirement, Migration and Welfare in the European Union, Policy Press, Bristol.

Ackers, L. and Dwyer, P. 2004. Fixed laws, fluid lives: the citizenship status of postretirement migrants in the European Union, Ageing and Society, 24, 3, 45176.

Anwar, M. 1979. The Myth of Return: Pakistanis in Britain, Heinemann, London.

Baldassar, L. and Baldock, C. 200o. Linking migration and family studies: transnational migrants and the care of ageing parents. In Agozino, B. (ed.) Theoretical and Methodological Issues in Migration Research:

Interdisciplinary, Intergenerational and International Perspectives, Ashgate, Aldershot, 61-89.

Baldassar, L. 2001. Visits Home: Migration Experiences between Italy and Australia, Melbourne University Press, Melbourne.

Baldwin-Edwards, M. 2004. Albanian emigration and the Greek labour market: economic symbiosis and social ambiguity, South-East Europe Review, 7, 1, 5166.

Barjaba, K. and King, R. 2005. Introducing and theorising Albanian migration. In King, R., Mai, N. and Schwandner-Sievers, S. (eds), The New Albanian Migration, Sussex Academic Press, Brighton, 1-28.

Brody, H. 1983. Inishkillane: Change and Decline in the West of Ireland, Jill Norman and Hobhouse, London.

Carletto, G., Davis, B., Stampini, M. and Zezza, A. 2004. Internal Mobility and International Migration in Albania, FAO ESA Working Paper 04-13, Rome. 
Casado-Díaz, M. A., Kaiser, C. and Warnes, A. M. 2004. Northern European retired residents in nine southern European areas: characteristics, motivations and adjustment, Ageing and Society, 24, 3, 353-81.

Dalipaj, M. 2005. Albanian Migration to the UK: A Hidden Migration?, University of Sussex, MPhil thesis in Migration Studies, Brighton.

De Soto, H., Gordon, P., Gedeshi, I. and Sinoimeri, Z. 2002. Poverty in Albania. A Qualitative Assessment, World Bank Technical Paper 520, Washington DC. de Zwager, N., Gedeshi, I., Germenji, E. and Nikas, C. 2005. Competing for Remittances, IOM Tirana, Tirana.

Fakiolas, R. 2003. Regularising undocumented immigrants in Greece: procedures and effects, Journal of Ethnic and Migration Studies, 29, 3, 539-61.

Government of Albania 2004. National Strategy on Migration. Tirana: Albanian Government and International Organisation for Migration.

Hermele, K. 1997. The discourse on migration and development. In Hammar, T., Brochmann, G., Tamas, K. and Faist, T. (eds), International Migration, Immobility and Development: Multidisciplinary Perspectives, Berg, Oxford, 133-59.

Hondagneu-Sotelo, P. and Avila, E. 1997. 'I'm here, but I'm there': the meanings of Latina transnational motherhood, Gender and Society, 11, 5, 548-71.

INSTAT 2002. The Population of Albania in 2001: Main Results of the Population and Housing Census, Instituti i Statistikës, Tirana.

INSTAT 2004a. Migration in Albania, Instituti i Statistikës, Tirana.

INSTAT 2004b. Albania Census Atlas 2001, Instituti i Statistikës, Tirana.

King, R., Strachan, A. and Mortimer, J. 1983. Return Migration: A Review of the Literature, Oxford Polytechnic, Discussion Papers in Geography 19, Oxford.

King, R. and Killingbeck, J. 1989. Carlo Levi, the Mezzogiorno and emigration: fifty years of demographic change at Aliano, Geography, 74, 2, 128-43.

King, R., Iosifides, T. and Myrivili, L. 1998. A migrant's story: from Albania to Athens, Journal of Ethnic and Migration Studies, 24, 1, 159-75.

King, R., Warnes, A. M. and Williams, A. M. 2000. Sunset Lives: British Retirement Migration to the Mediterranean, Berg, Oxford.

King, R. 2003. Across the sea and over the mountains: documenting Albanian migration, Scottish Geographical Journal, 119, 3, 283-309. 
King, R., Mai, N. and Dalipaj, M. 2003. Exploding the Migration Myths: Analysis and Recommendations for the European Union, the UK and Albania, The Fabian Society and Oxfam, London.

King, R. and Vullnetari, J. 2003. Migration and Development in Albania, University of Sussex, Development Research Centre on Migration, Globalisation and Poverty, Working Paper $\mathrm{C}_{5}$, Brighton.

King, R. 2004a. Albania: interrelationships between population, poverty, development, internal and international migration, Méditerranée, 103, 3-4, $37-47$.

King, R. 2004b. What mass migration means for older people left behind: notes from the field in Albania. In Warnes, T. (ed.) Older Migrants in Europe: Essays, Projects and Sources, Sheffield Institute for Studies on Ageing, Sheffield, 6670.

King, R. and Mai, N. 2004. Albanian immigrants in Lecce and Modena: narratives of rejection, survival and integration, Population, Space and Place, 10, 6, 455-77.

King, R. 2005. Albania as a laboratory for the study of migration and development, Journal of Southern Europe and the Balkans, 7, 2, 133-55.

Konidaris, G. 2005. Examining policy response to immigration in the light of interstate relations and foreign policy objectives: Greece and Albania. In King, R., Mai, N. and Schwandner-Sievers, S. (eds), The New Albanian Migration, Sussex Academic Press, Brighton, 64-92.

Kreager, P. 2006. Migration, social structure and old-age support networks: a comparison of three Indonesian communities, Ageing and Society, 26, 1, 3760.

Kule, D., Mançellari, A., Papapanagos, H., Qirici, S. and Sanfey, P. 2002. The causes and consequences of Albanian emigration during transition: evidence from micro-data, International Migration Review, 36, 1, 229-39.

Lowenthal, D. and Comitas, L. 1962. Emigration and depopulation: some neglected aspects of population geography, Geographical Review, 52, 2, 195-210.

Nicholson, B. 2001. From migrant to micro-entrepreneur: do-it-yourself development in Albania, South-East Europe Review, 4, 3, 39-41.

Nicholson, B. 2004. The tractor, the shop and the filling-station: work migration as self-help development in Albania, Europe-Asia Studies, 56, 6, 877-90. 
Nikas, C. and King, R. 2005. Economic growth through remittances: lessons from the Greek case of the 1960 s applicable to the Albanian case, Journal of Southern Europe and the Balkans, 7, 2, 235-57.

Olsen, N. 2000. Albania, Oxfam Country Profile, Oxford.

O'Reilly, K. 2000. The British on the Costa del Sol: Transnational Identities and Local Communities, Routledge, London.

Orgocka, A. 2005. Albanian high-skilled women in the US: the ignored experience. In King, R., Mai, N. and Schwandner-Sievers, S. (eds), The New Albanian Migration, Sussex Academic Press, Brighton, 139-52.

Piperno, F. 2005. Albanian migrants' remittances: a development opportunity? In King, R., Mai, N. and Schwandner-Sievers, S. (eds), The New Albanian Migration, Sussex Academic Press, Brighton, 118-38.

Psimmenos, I. and Kassimati, K. 2003. Immigration control pathways: organisational culture and work values of Greek welfare officers, Journal of Ethnic and Migration Studies, 29, 2, 337-71.

Rodríguez, V., Fernández-Mayoralas, G. and Rojo, F. 1998. European retirees on the Costa del Sol: a cross-national comparison, International Journal of Population Geography, 4, 2, 183-200.

Russell, S. S. 1986. Remittances from international migration: a review in perspective, World Development, 14, 6, 677-96.

Russell, S. S. 1993. Migrant remittances and development, International Migration, 31, 3-4, 267-87.

Sivignon, M. 1995. La population albanaise: une ère nouvelle, Méditerranée, 83, 1-2, 47-52.

Sjöberg, Ö. 1989. A note on the regional dimensions of post-war demographic development in Albania, Nordic Journal of Soviet and East European Studies, 6, 1, 91-121.

Sokoli, N. and Axhemi, S. 2000. Emigration in the period of transition in Albania, Studi Emigrazione, 37, 139, 521-9.

Stampini, M., Davis, B. and Carletto, G. 2004. Familiar Faces, Familiar Places: The Role of Family Networks and Previous Experience for Albanian Migrants, FAO ESA Working Paper 04-14, Rome. 
Accepted Manuscript (AM) of King, R. and Vullnetari, J. (2006) 'Orphan pensioners' and 'migrating grandparents': The impact of mass migration on older people in rural Albania. Ageing \& Society 26(2): 783-816 [DOI: 10.1017/So144686X06005125][accepted o6 February 2006; published October 2006].

Taylor, E. 1999. The new economics of labour migration and the role of remittances in the migration process, International Migration, 37, 1, 63-86.

UNDP 2005. National Human Development Report Albania 2005: Pro-Poor and Pro-Women Policies and Development in Albania. Tirana: UNDP.

Vullnetari, J. 2004. 'Like Stones in the Middle of the Road': The Impact of Migration on Older Persons in Rural Albania, University of Sussex, MSc dissertation in Migration Studies, Brighton.

Warnes, A. M. 2001. The international dispersal of pensioners from affluent countries, International Journal of Population Geography, 7, 5, 373-88.

White, P. E. 1980. Migration loss and the residual community: a study in rural France, 1962-1975. In White, P. E. and Woods, R. I. (eds), The Geographical Impact of Migration, Longman, London, 198-222.

Zontini, E. 2001. Family formation in gendered migrations: Moroccan and Filipino women in Bologna. In King, R. (ed.) The Mediterranean Passage: Migration and New Cultural Encounters in Southern Europe, Liverpool University Press, Liverpool, 231-57.

Zontini, E. 2004. Immigrant women in Barcelona: coping with the consequences of transnational lives, Journal of Ethnic and Migration Studies, 3o, 6, 1113-44.

\section{Notes}

\footnotetext{
${ }^{1}$ The interviewers were Mirela Dalipaj and Nicola Mai, co-authors of the study which reported the general results of the Oxfam project. A preliminary analysis of the 'orphan pensioners' theme, based on these north Albanian interviews, was made by King (2004b). See also the MPhil thesis of Dalipaj (2005) which spun out of the Oxfam research.
}

2 A first analysis of some of these interviews is in Vullnetari's MSc dissertation (2004); other interviews are part of the same author's ongoing DPhil research at the University of Sussex.

3 In order to ensure anonymity, no names of villages are revealed in our account, and the names of interviewees are pseudonyms. Many people in Albania, especially older persons, still feel uneasy about being interviewed; due to their experience in communist times, they are reluctant to speak openly about officialdom, fearing persecution. For this reason, confidentiality and anonymity were repeatedly assured, and the main topics of the interviews avoided sensitive questions, focusing instead on everyday activities of the respondents, their families, their feelings about the migration of their children, and their plans and thoughts about the future. Most interviews were taped and then 
Accepted Manuscript (AM) of King, R. and Vullnetari, J. (2006) 'Orphan pensioners' and 'migrating grandparents': The impact of mass migration on older people in rural Albania. Ageing \& Society 26(2): 783-816 [DOI: 10.1017/So144686X06005125][accepted o6 February 2006; published October 2006].

subsequently translated and transcribed; in those cases where the interviewees did not want to be recorded, detailed notes were taken during and after the interview.

4 In the case of one of the authors, this involved her personal experience of living in and emigrating from an Albanian village, including the ensuing transnational kin relationships and responsibilities.

5 It may also be the case that parents are not fully aware of the nature of the experience - and suffering - of their children's emigration since they will have been 'shielded' by their children not telling them the 'whole story'.

${ }^{6}$ For the general debate see Hermele (1997), Russell (1986; 1993) and Taylor (1999), and for overviews of the Albanian situation see de Zwager et al. (2005), Nikas and King (2005) and Piperno (2005).

7 Some recent developments in Qazime's family situation: in 2005 her son came to visit from Australia, staying several months. Then, both grandsons came to visit too. These visits had a very important aim: to seek future brides for the grandsons. The father prepared the ground after reconnaissance work, and then his sons came to see and be seen and thus finalise the process. Once the engagements had been made, they all left; the fiancées will join them once the paperwork has been completed. All this makes Qazime's hope of her family's 'final return' even more remote. After talking to them personally, it became very clear that, whilst the father, Refik, contemplates a return to Albania upon retirement (but the realisation of this must be seen as doubtful), the young men did not have the slightest intention of returning.

8 The high numbers reveal on the one hand the massive scale of the Albanian migration to Greece; on the other hand they also suggest that many of these expulsions are of 'repeat migrants' who were continually entering, getting expelled and re-entering within a short space of time. For a detailed account of how the timing of these repatriations was related to the broader geopolitics of GreekAlbanian international relations see Konidaris (2005).

9 A lottery scheme whereby the US Immigration and Naturalization Service makes available around 55,000 green cards every year for countries with low numbers of emigrants to the US. Albanians have been remarkably successful with this scheme.

10 This is an old tradition in pre-communist Albania, where the practice of kurbet - the man working away from home to support his family - was widely followed under the Ottoman Empire (see Barjaba and King 2005: 9-10).

${ }_{11}$ There is another form of cross-border care, which takes place when young children are cared for by their grandparents in Albania, thereby enabling both parents to work abroad. This strategy is not very common, and occurs especially when the migrants are irregular and the grandparents are denied visas. This is more the case for migrants in Greece, and sometimes in Italy; geographical proximity is a factor. However, this arrangement obviously separates parents from their children at a crucial stage of the latter's development.

${ }^{12}$ For a study of high-skilled Albanian women who have emigrated to the US see Orgocka (2005).

${ }_{13}$ Probably he will find work in garages, car-washes etc., as he did on his previous visit to the US, when he stayed eight months. 
Accepted Manuscript (AM) of King, R. and Vullnetari, J. (2006) 'Orphan pensioners' and 'migrating grandparents': The impact of mass migration on older people in rural Albania. Ageing \& Society 26(2): 783-816 [DOI: 10.1017/So144686X06005125][accepted o6 February 2006; published October 2006].

14 On the other hand, we do not discount the possibility that some children, including the youngest son, might migrate in order to release themselves from familial obligations or as a form of rejection of their 'traditional duties'. Interviews with migrants in the UK reveal both commitment and devotion to materially supporting their parents in Albania, but also, in some cases, much guilt, ambivalence and a sense of being over-burdened. See King, Mai and Dalipaj (2003: 55-6) 